\title{
XLVII. An attempt to classify certain luminous phænomena observed about the sun and moon
}

\section{Thomas Forster Esq.}

To cite this article: Thomas Forster Esq. (1811) XLVII. An attempt to classify certain luminous phænomena observed about the sun and moon , Philosophical Magazine Series 1, 38:162, 259-262, DOI: $10.1080 / 14786441108638643$

To link to this article: http://dx.doi.org/10.1080/14786441108638643

里 Published online: 27 Jul 2009.

Submit your article to this journal $₫$

Џll Article views: 2

Q View related articles 두 
nent sculptors and painters in this metropolis) have publicly and unequivocally declared, that, in the view of professional men, this collection must be far more valuable than any other collection in existence."

Two suggestions have met with much approbation, in a view to the improvement to be obtained to sculpture from these marhles and casts-r'The first, that casts of all such as were ornaments on the temples should be placed in an elevation, and in a situation, similar to that which they actually had occupied; that the originals should be disposed in a view to the more easy inspection and study of them; and that particular subjects should occasionally be selected, and premiums given for the restoration of them. This restoration to be executed on casts, but by no means on the originals; and in the turuseum itself, where the character of the sculpture might be the more readily studied.

"Secondly: From trials which lord Elgin was induced to make at the request of professional gentlemen, a strong impression has been created, that the science of sculpture, and the taste and judgement by which it is to be carried forward and appreciated, cannot so effectually be promoted as by athletic exercises practised in the presence of similar works; the distinguishing merit of which is an able, scientific, ingenious, but exact imitation of nature. By no other way could the'variety of attitude, the articulation of the muscles, the description of the passions; in short, every thing a sculptor has to represent, be so accurately or so beneficially understood and represented.

c Under similar advantages, and with an enlightened and cncouraging protection besiowed on genius and the arts, it may not be too sanguine to indulge a hope, that, prodigal as nature is in the perfections of the human figure in this country, animating as are the instances of patriotism, heroic actions, and private virtues, deserving commemoration, sculpture may soon be raised in England to rival the ablest productions of the best times of Greece."

XLVII. An Attempt to classify cortain luminous Phanomena observed alout the Sun and Moon. By THOMAS FORSTER, Esq.

To Mr. Tilloch.

Sir, I shatr have frequent occasion, in meteorological observations intended to be communicated through the medium of the Philosophical Magazine, to mention certain 
260 An Attempi to classify certain luminous Phanomena.

luminous appearances observed about the sun and moon, and occasioned by the refraction of their light through an intervening cloud of peculiar structure, which are in common called halos, coronæ, burs, \&c. But as these phanomena vary considerably, and as I know of no existing nomenclature calculated to express, with precision, their several appearances; and as the above terms are very frequently confused with one another, I-shall take the liberty to offer one, which, however imperfect, may serve till a better shall be found. I shall endeavour to classify them (for want of a better criterion) according to the various shapes or figures which they present. It must be remembered, that their various figures are the result of the particular construction of the cloud which refracts their light: a correct attention, therefore, to these appearances may lead to a more perfect knowledge of the structure of the refracting medium.

HaLO*. Def, Circulus vel anmulus lucidus aream includens, in cujus centro sol aut luna apparet.

Olser. By a halo $\mathrm{t}$ understand an extensive luminous ring, including a circular area, in the centre of which the sun or moon appears, whose light, refracted through the intervening cloud, gives rise to the phænomenon. Halones. are called lunar or solar, according as they appear round the moon or sun. They are generally pretty correct circles; I once, however, saw a halo of a somewhat oval figure. Halones are sometimes coloured with the tints of the rainbow.

Halo duplex. Def. Duo annuli, in quorum centro communi sol aut luna videatur.

Obser. A double halo is not a very common occurrence, I have observed that simple halones are generally about $\mathbf{4 5}$ degrees in diameter: in case of double halo, it might be worth whlle to take the diameters of each of the concentric circles.

Halo TRIPLEX. Def. Tres annuli, in quoram centro communi sol aut luna apparet:

Obser. Triple halones are extremely rare occurrences.

Halo orscoides. Def. Annulus aream reliquâ nulis parte lucidiorem continens, in eijus centro luna aut sol visus est.

Olser. A discoid halo may be said to be a halo consti-

* The word halis or halos is evidently derived from the Greek " $\ddot{\lambda} \lambda$ ar or ä $\lambda$ ws, rignifying an area. The Latin writers appear to have; spokena jidifferently of halones, halyses, coronx, circuli, \&c. without sufficiehtly distinguishing between the corona and the halo-in other words, betweòn' the lumirious disk and the luminous ring. 
tuting the boundary of a large corona : it is generally of less diameter than usual, and often coloured with the tints of the $i$ ris. A beautiful one appeared on the $22 \mathrm{~d}$ of December 1809 , about midnight, during the passage of a cirrostratus before the moon.

Corona. Def. Discus lucidus, vel portio circularis nubis reliquâ lucidior, in cujus centro sol aut luna videtur.

Otser. When the sun or moon is seen through a thin cloud, a portion of the cloud, more immediately round the sun or moon, appears much lighter than the rest of it: this luminous disk, if I may be allowed the expression, I call a corona.

Coronze are of various sizes, according to the peculiarities of the refracting vapour: but they seldom exceed $10^{\circ}$ in diameter; they are generally faintly coloured at their edges.

Frequently, when there is a halo encircling the moon, there is a small corona more inmediately round it. Coronx, as well as balones, have been always observed to prognosticate rain, hail, or snow. As far as I can observe, they are generally seen in the cirrostratus cloud.

Corona Duplex. Def. Discus lucidus, alium discum paulo lucidiorem ac minorem includens, in quorum centro communi sol vel luna observatur.

Oliser. A double corona is very common; but I never remember to have seen a triple one.

Parhacion. Def. Imago solis falsa, vel plures imagines ejusdem generis circa solem circulatim disposita, et magis minúsue halonibus aliisque lucidis vittis comitate.

Obser. Parbelia vary considerably in general appearance; sometimes the sun is encircled by a large balo, in the circumference of which the mock suns usually appear: these have often small halones round them: they have usually a horizontal band of white light of a pyramidal figure extending from them: sometime; a large semicurcular band of light, like an inverted arch, seems to rest upon the halo which encircles the sun: but these phæmomena vary too much to be particularly described here : their peculiar.ties ought to be ninutely observed and noted down in a meteorological journal.

Paraselene. Def. Luna imago falsa, vel plures imagines hujus generis circa lunam dispositce, et magis minúsve hulonilus aliisgue lucidis vittis comitatce.

Obser. The paraselene, the parhelion, and the several kinds of halo and corona, all appear to be the consequence R 3 
262 Description and Analysis of a Meteoric Stone.

of the intervention of cloud between the spectator and the sun, moon, or planet, the peculiar refraction of which causes the appearance : but there is another well-known phænomenon which always appears in a cloud opposite to the sun or moon, namely the

IrIs. Def. Circulus maximus coloratus in nule soli oppositá visus, qui, quòd portio ejus tantùm videatur, arcus appareat.

Oliser. The rainbow is too familiar to every one to need any particular description.

IrIS DUPLEX. Def. Duo circuli maximi colorati, quorum centro communi sol oppositus est; qui, quòd eorum portiones tantùm videantur, arcus appareant.

olser. Irises or rainbows always appear in the nimlus when that cloud is pouring down rain from a situation opposite to the sun.

Concerning the cause of halones, \&c. all that can be said is, that these phænomena must depend on some peculiar unexplored structure of the refracting cloud, I believe, always a cirrostratus, in cases of halo, parhelion, and paraselene; though a corona is sometimes seen in thin flimsy confluent cirrocumulus. To me it appears that the angle of the semidiameter of a halo must always correspond with the angle at which the rays are refracted, as they must all fall physically parallel on every part of the cloud.-For more particulars relative to the structure of clouds refracting these phænomena I must refer your readers to Phil. Trans, vol, v. 1065 ;-xxii. 535 ;-xxxi. 212 ;-xxxix. 118 ;-xlvi. 196;lii. 3 ;-M. Helvetius, end of "Merc. in Sole;"-Des Cartes's Freatise of Meteors;-M. Huygens's Posth. Wurks, p.293; and Newton's Optic. Ist edit. p. 134.

ThOMAS FORSTER.

XLVIII. Descriplion and Analysis of a Meteoric Stone which fell in the County of Tipperary, in Ireland, in the Month of August 1810. By William Higgins, Esq.

To $M r$. Tilloch.

Dear Sir, As meteoric stones have lately engaged tho attention of the philosophical world, perhaps the following description and analysis of a stone that had fallen last August, during a thunder-storm, in the county of Tipperary, in Ireland, very near the house of Maurice Crosbie Moore, esq. will be acceptable to many of the numerous readers of your very useful Journal. It will at least add to the authenticity 